\title{
DEVELOPMENT OF UNIMPROVED SCRUBLAND
}

\author{
By J. BRUCE BROWN, Lands and Survey Depart- \\ ment, Wellington.
}

This paper is not intended to deal in detail with the methods of development of unimproved scrubland in North Auckland, that aspect will be covered in the field this afternoon. At this stage I propose to mention more particularly the background of North Auckland country-vegetative cover and tenure-the present activities of the Lands and Survey Department in classifying sill unimproved land, and the development of unimproved Crown land.

Kirk writing in 1869 said' of Whangarei northward: "The general vegetation over the whole country is alternate bush, open scrubby land, and open fern land, there being very little natural grass land, the largest area being at the North Cape and even there the prevailing species are not indigenous to New Zealand. The whole country has been at no distant time covered by bush . . ."

\section{DEVELOPMENT OVER THE YEARS}

It has been established that a-large-area-of-North Auckland was originally in native bush, and it is interesting to note its rapid reduction in area during the past 100 years.

$$
\begin{aligned}
& 1850-2,240,000 \text { acres } \\
& 1893-\mathbf{1 , 8 0 0 , 0 0 0} \text { acres } \\
& 1950-479,000 \text { acres }
\end{aligned}
$$

Much of the land which was in native bush is now the scrub country we are to discuss today. Those who plough this land are often made aware of this fact very forcibly when their-implements-strike--akauri stump beneath the surface.

The preliminary utilisation survey shows that the farmable country can be broken up into the following categories. 
Good pasture

161,000 acres (only 7 per cent)

Indifferent pasture $\mathbf{1 , 3 4 0 , 0 0 0}$ acres

Unimproved

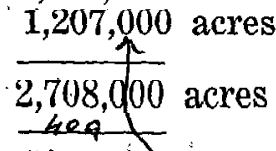

$x_{3}$

Of the unimproved areas $\backslash 409,000$ acres are low fertility land which may not come into production until the more attractive lands'are developed. There are, however, some 798,000 acres of readily developable unimproved land in North Auckland today ; somebddy said recently that New Zealand was almost fully developed.

A large proportion of the 798,000 acres was included in existing farms or already included in the blocks -under development by the Superintendent of Land Development, but larger blocks totalling 228,000 acres were selected for closer investigation.

The tenure position of these blocks was as follows :-

\begin{tabular}{lr} 
Freehold & 128,000 acres \\
Maori land & 46,000 acres \\
Crown & 28,000 acres \\
Crown lease & 26,000 acres \\
\cline { 2 - 2 } & 228,000 acres
\end{tabular}

It is expected that the more intensive survey now being undertaken will increase this total figure quite materially.

\section{OVERALL TENURE POSITION, 1950-51}

The following was the approximate tenure position of North Auckland at the above date.

Freehold and permanent Crown lease 2,378,700 acres Crown land . . . . 436,246 acres Maori land . . . . . 4 412,300 acres State Forest . . . . 119,200 acres Reserves . . . . . . $\quad$. 35,430 acres

Total $3,381,876$ acres

Note: Balance to $3,790,000$ acres previously quoted is made up of areas under 50 acres, roads, rivers, lakes, harbours, etc., not included above. 


\section{CLASSIFICATION OF UNALIENATED CR̈OWN \\ LAND}

In December 1952' a classification- of unalienated Crown land was undertaken to -ascertain what areas 'at present held 'by the Crown were immediately available for development.

The main groups from this investigation are set out below :-

Suitable for immediate development 93,000 acres

Suitable for deferred development . $\mathbf{5 3 , 0 0 0}$ acres

Suitable for experimental development $\mathbf{7 4 , 0 0 0}$ acres (mainly Mangonui County)

Swamps under investigation . . 14,000 acres

Total : $\overline{\mathbf{2 3 4 , 0 0 0}}$ acres

\section{CROWN OPERATIONS}

Development from unimproved :

For the past 3 years the Lands and Survey Department has developed from unimproved and sown in permanent pasture the following areas in North Auckland :

$\mathbf{1 9 5 0 - 5 1}$
$1951-52$
$1952-53$$\quad \cdot \quad \begin{gathered}4,898 \text { acres } \\ 10,507 \text { acres } \\ 9,607 \text { acres }\end{gathered}$
acres

The estimate for the 'coming season is 13,730

As will be appreciated, much depends on the weather when a programme such as the: above is being undertaken and-in-North-Auckland more than in most places wet spells at the critical time of the year will render the ground unfit for sowing for a further 12 months. To sow the 13,730 acres over half a million lb. of grass and clover seed will be required and some 2000 tons of manure. Incidentally the total requirements of the Superintendent of Land Development, North Auckland, for manure in the current season amount to 8614 tons.

\section{Land under development :}

The land on the books of the Superintendent at present totals_92,500-aeres and of this approximately 30,000 acres are in grass. It is estimated that the portion of this land being developed for settlement will eventually yield 150 "dairy and 80 sheep farms. Approximately 12,000 acres subdivided into 40 units will be handed over for settlement next autumn 


\section{Soil Types:}

The main soil types under development are volcanic, clay, gum clay, ironstone, peat, and consolidated sand. As a result of the combined: efforts of those who carried out experiments in the past, no real difficulties are now apparent in developing and establishing pasture on all these types of soil. Thus I think it can be said with confidence that provided the contour is reasonable, by far the largest proportion of the soils of North Auckland which were termed "problem soils" in the past can now be developed for farming.

\section{Water Supplies :}

One of the greatest problems in some areas is procuring a satisfactory water supply. The Crown has men working on this aspect all the time, but much more has still to be done before the district has been fully investigated and the most satisfactory means of supply determined.

stock :

When land is being developed in large areas stock play an important part, particularly in the early stages. The availability of suitable stock in North Auckland for this purpose has caused the Department considerable trouble and at present it is necessary to bring sheep from as far afield as Hawke's Bay to meet requirements.

The Lands Department regards the improvement of the standard of stock as almost as important as the improvement of land, and much time is spent selecting good stock for breeding. By this means it is hoped that a further contribution is being made toward the development of the country in the north.

\section{GENERAL}

In the past the tendency has been toward dairy' ing, but with the spread of the development of land to the steeper country and land where water is not readily available, a greater number of sheep and run cattle must come in-in my opinion a desirable change in the interests of the future welfare of the north generally.

Quite apart from the development by the Crown (Departments of Maori Affairs and Lands and Survey) there is ample evidence of new country being brought in by private enterprise; it can be seen from the roads as you drive through and is also apparent from the number of Marginal Lands loans already approved by the Lands and Survey Department. 


\section{FACILITIES}

In the past the general facilities of the north have been lacking, in particular good roading and lime and manure in sufficient quantities at a reasonable cost (due to cartage costs). This situation is improving and so it must if the possible future requirements are to be met. If the main farmable areas were in grass, at least 400,000 tons of lime and 300,000 tons of manure would be required for maintenance alone.

\section{SUMMARY}

1. There is considerable potential production in $1,340,000$ acres of land at present in indifferent pasture north of Auckland City.

'2. There are approximately 1,207,000 acres of farmable unimproved land in the same 'districts.

3. Of this 1,207,000 acres approximately five-sixths is privately held.

4. There is ample evidence of growing confidence in the farming future of North 'Auckland and the development of many types of soil is proceeding at a good pace.

\section{DISCUSSION}

Q. The opinion is current that the Marginal Lands Act is stringently administered and that money is not being made freely available for private development. Are there any views on a more liberal interpretation of the Marginal Lands Act so that 5-6ths of the land privately held in North Auckland can be developed?

A. Administration of the Marginal Lands Act is a matter of Government policy. It can be said though that a considerable amount of money is coming to North Auckland at present under the Act. Providing a farmer cannot get money from, another lending institution, the Marginal Lands Board will give his application serious consideration. Tf the property for which an application is made is already a sound unit, preference must be given to others truly marginal. It has been said that assistance will apply only to marginal land. This is not wholly true; it applies more to a marginal proposition. It might be the best land in New Zealand, but if it is a marginal proposition economically, the owner can get assistance.

Q. At what stage of development are blocks considered suitable for handing over to settlers?

A. We have to take a risk in the early stage at which we hand over a lot of our farms to settlers. There is naturally a wish to get rehabilitation duties discharged as soon as possible. There must be a risk if the land is to be handed, over quickly. With civilian settlement coming on later there may be a change. Generally we like to see the property at a stage where a man can pay his way. We could hand over earlier but do not favour it. We know the settler will get problems with ragwort, seedling gorse, and manuka, but the average man could make a do with anything he gets. 